\title{
Kajian Komparatif Parameter Kualitas Tanah di Beberapa Tataguna Lahan Sub DAS Cisadane Hulu dengan Pb-210 excess dan Cs-137
}

\author{
Comparative Study of Soil Quality Parameters on Several \\ Landuses in The Upstream of Cisadane Sub-basin with Pb-210 \\ excess and Cs-137
}

\section{Barokah Aliyanta}

Pusat Aplikasi Isotop dan Radiasi, BATAN

Jl. Lebak Bulus Raya No. 49, Jakarta 12440

Email : barali@batan.go.id

Diterima 05-10-2015; Diterima dengan revisi 23-10-2015; Disetujui 19-11-2015

\begin{abstract}
ABSTRAK
Kajian Komparatif Parameter Kualitas Tanah di Beberapa Tataguna Lahan Sub DAS Cisadane hulu dengan Pb-210 excess dan Cs-137. Analisis inventori $\mathrm{Pb}-210$ excess dan Cs-137 serta parameter kualitas tanah dan estimasi laju erosi telah dilakukan di 4 tataguna lahan di sub DAS Cisadane Hulu. Pengambilan sampel tanah dilakukan dengan alat corer sampai kedalaman $20 \mathrm{~cm}$ pada tiap tataguna lahan secara transek. Satu sampel scrap dan 4 sampelcoresdiambil di Hutan Pinus, Pasir Jaya, untuk mendapatkan inventori pembanding.Erosi yang cukup serius telah terjadi di 4 tataguna lahan di sub DAS Cisadane Hulu. Kandungan $\mathrm{Pb}-210$ excess mempunyai korelasi positif dengan kandungan organik karbon tanah $(79 \% \mathrm{C})$ dan kandungan nitrogen $(56 \% \mathrm{~N})$ dalam tanah, sedangkan Cs-137 berkorelasi positif masing-masing dengan $23 \% \mathrm{C}$ dan $33 \% \mathrm{~N}$ dalam tanah. Fakta-fakta ini memberikan informasi bahwa inventori Pb-210 excess lebih efektif dari inventori Cs-137 sebagai sarana untuk mempelajari dinamika transport karbon akibat erosi maupun mengetahui status kualitas tanah.
\end{abstract}

Katakunci : parameter kualitas tanah, $\mathrm{Pb}-210$ excess, Cs-137, inventori

\begin{abstract}
Comparative Study of Soil Quality Parameters on Several Landuses in the Upstream of Cisadane Sub-basin with $\mathrm{Pb}-210$ excess and Cs-137. Analysis of inventory $\mathrm{Pb}-210$ excess and Cs-137 as well as soil quality parameters and estimation of the rate of erosion has been conducted in four land-uses in the upstream of Cisadanesub-basins. Soil sampling was performed with a corer to a depth of $20 \mathrm{~cm}$ on each land use transectly. One scrap sample and 4 cores were taken at Pine Forest, Pasir Jaya, forreferenceinventory purpose. Serious erosion has occurred in four land uses in the upstream ofCisadanesub-basins. The content of $\mathrm{Pb}-210$ excess has positively correlated with the organic content of soil carbon $(79 \% \mathrm{C})$ and nitrogen content $(56 \% \mathrm{~N})$ in the soil, whereas Cs-137 has positively correlated with $23 \% \mathrm{C}$ and $33 \%$ of $\mathrm{N}$ in the soil. These facts give the information that the $\mathrm{Pb}-210$ excess inventory is more effective than the inventory of Cs-137 as a means for studying the dynamics of carbon transport as a result of erosion and for determination of the status of soil quality.
\end{abstract}

Keywords : soil quality parameters, $\mathrm{Pb}-210$ excess, Cs-137, inventory 


\section{PENDAHULUAN}

Seiring dengan kemajuan ilmu semikonduktor dalam sistem elektronik peralatan modern dan berkembangnya pemodelan matematika, pemanfaatan radionuklida jatuhan Cs-137 dan $\mathrm{Pb}$ 210excessyang ada pada tanah semakin tumbuh pesat sebagai perunut dalam penelitian terkait dengan lingkungan terrestrial seperti geokronologi proses sedimentasi. Perunut antropogenik Cs-137 dan $\mathrm{Pb}-210$ excess alam ini merupakan salah satu metoda yang berkembang cukup pesat dalam pemanfaatannya untuk mengidentifikasi redistribusi tanah pada suatu lahan atau dalam suatu cacthment [13], dan untuk mengkaji efektivitas konservasi pengelolaan lahan yang diaplikasikan di lapangan [4]. Radionuklida Cs-137 merupakan isotop radioaktif yang berasal dari lepasan dalam percobaan senjata nuklir pada dekade 1950-an sampai 1970-an, dan secara global telah terdeposisi ke tanah, tidak mengalami pertukaran dan dapat digunakan sebagai perunut akibat dari proses redistribusi tanah [5]. Cs-137 mempunyai waktu paruh sebesar 30,2 tahun dan dapat digunakan untuk estimasi redistribusi tanah selama kurun waktu 50 tahun. Dibandingkan dengan belahan bumi bagian utara, aktivitas Cs-137 di belahan bumi bagian selatan lebih sulit diukur karena kecilnya aktivitas deposisi dan akibat peluruhan radioaktif, serta tidak adanya lagi masukan. Fakta ini sering menjadi kendala dalam memanfaatkan teknik Cs-137 dalam penelitian erosi belahan bumi bagian selatan, seperti Indonesia [6]. Mengingat aktivitas yang akan diukur sangat kecil, maka perlu diupayakan bahwa laboratorium pengukuran harus bebas dari kontribusi sumber gamma buatan dari lingkungan.

Lain dengan Cs-137, Pb-210 excess merupakan radionuklida alam yang pada awalnya banyak digunakan untuk penanggalan umur terkait dengan laju sedimentasi maupun estimasi fluks dan kronologi polutan $[7,8]$. Pb-210 excess merupakan radionuklida yang berasal dari peluruhan Uranium-238. Pb-210 excess mempunyai waktu paruh 22,26 tahun. Seperti halnya Cs-137, Pb-210 excess teradsorpsi secara kuat oleh partikel tanah, sehingga dapat dijadikan juga sebagai perunut redistribusi tanah yang disebabkan oleh proses erosi dan deposisi. Keberadaan $\mathrm{Pb}-210$ excess dalam udara dimulaidengan peluruhan Ra-226 yang berasal dari Uranium-238 dalam kerak bumi menjadi gas Rn-222 dengan waktu paruh 3,8 hari dan meluruh melalui deretan anak luruhnya menjadi Pb-210 [9]. Ada dua sumber utama $\mathrm{Pb}-210$ yang terikat pada partikel tanah yaitu yang pertama berasal dari udara sebagai partikel aerosol yang beterbangan dan mengendap bersama air hujan atau deposisi basah ke permukaan tanah dan yang kedua berasal dari tanah itu sendiri. $\mathrm{Pb}-210$ excess akan diproduksi secara terus menerus dan aktivitas jatuhannya tidak bergantung pada waktu tetapi bergantung pada jenis batuan/tanah setempat.

$\mathrm{Pb}-210$ excess dalam tanah akan di adsorpsi partikel halus tanah secara kuat, sehingga dapat dijadikan sebagai perunut pergerakan tanah karena aliran permukaan. Jatuhan $\mathrm{Pb}-210$ excess dari udara ke permukaan tanah dan teradsorpsi oleh partikel halus tanah dikenal sebagai $\mathrm{Pb}-210$ unsupported, sedangkan $\mathrm{Pb}-210$ yang berasal dari tanahnya sendiri dikenal sebagai $\mathrm{Pb}-210$ supported. Pemanfaatan $\mathrm{Pb}-210$ excess inipun sekarang telah dikembangkan untuk perunut dalam mengindentifikasi daerah sumber sedimen [10]. Karena sumber jatuhan yang tersedia terus menerus membuat $\mathrm{Pb}-210$ excess dapat dimanfaatkan untuk kajian laju erosi lebih dari 100 tahun.

Secara prinsip, informasi kualitatif terjadinya proses erosi dan atau deposisi di suatu lahan adalah dengan membandingkan inventori $\mathrm{Cs}-137$ dan atau $\mathrm{Pb}-210$ excess pada daerah pembanding dengan daerah yang diteliti. Bila nilai inventori di daerah pembanding lebih besar dari daerah yang diteliti, maka pada daerah yang diteliti telah terjadi erosi. Sebaliknya, bila daerah pembanding lebih kecil dari daerah yang diteliti, maka pada daerah yang diteliti telah 
terjadi deposisi [11,12]. Pengamatan di lapangan pada saat hujan dapat memperlihatkan aliran permukaan yang membawa partikel tanah hasil erosi sekaligus memperkirakan tempat terjadinya erosi maupun deposisi. Proses perpindahan partikel tanah oleh erosi/deposisi dapat terjadi berulang-ulang dan sangat dipengaruhi beberapa faktor yaitu curah hujan baik lama dan intensitasnya, cara mengolah tanah dan kesesuaian lahan untuk kegiatan pertanian dimaksud.

Erosi yang berlangsung terus menerus pada suatu lahan akan menyebabkan terjadinya penurunan kesuburan lahan yang ditandai dengan semakin rendahnya unsur hara yang dapat menghambat pertumbuhan tanaman dan menurunkan hasil panen di daerah on-site. Disamping itu, erosi yang berlangsung terus menerus dapat menaikkan beban angkutan sedimen di sungai dan pendangkalan di daerah off-site. Dengan semakin terbatasnya sumberdaya lahan/tanah untuk kegiatan pertanian, kajian untuk mengetahui efektifitas pengelolaan lahan dalam pemanfaatan lahan untuk pertanian yang berkelanjutan menjadi prioritas utama.

Penelitian ini ditujukan untuk mengetahui apakah pengelolaan dan pemanfaatan lahan telah efektif didasarkan pada kajian parameter kualitas tanah, laju erosi berdasarkan model konversi radionuklida $\mathrm{Pb}-210$ excess dan Cs-137 dari masing-masing transek pada tataguna lahan. Selain itu, hal ini penting untuk dianalisis lebih lanjut terkait dengan kemungkinan pemanfaatan lain dari radionuklida ini sebagai perunut, khususnya terkait dengan dinamika karbon dalam tanah.

\section{BAHAN DAN METODE}

\section{Daerah penelititan}

Lokasi penelitian terletak di kawasan daerah aliran sungai (DAS) Cisadane yang terdiri dari empat tata guna lahan yaitu, (1) kebun teh (KT), (2) tanaman rumput gajah untuk makanan ternak (RT), (3) tanaman keras tumpangsari dengan tanaman semusim (KS) dan (4) ladang yang digunakan untuk rotasi tanaman semusim (TS). Kebun teh yang tidak terurus dengan baik merupakan kebun teh peninggalan zaman kolonial yang terletak di Dusun Cipelang dengan koordinat $06^{\circ} 41,5^{\prime}$ LS dan $106^{\circ} 46,9^{\prime}$ BT serta ketinggian berkisar $600-700 \mathrm{~m}$ diatas permukaan laut (dpl). Tanaman rumput gajah ditanam pada lahan berlereng dengan memberikan pupuk kandang dari hasil kotoran sapi dengan koordinat lokasi $06^{\circ} 42,55^{\prime}$ LS dan $106^{\circ} 45,98^{\prime}$ BT dengan ketinggian berkisar 1100-1110 m dpl. Tataguna lahan tanaman keras dengan tumpang sari tanaman semusim di Pasir Buncir dengan koordinat $06^{\circ} 44,90^{\prime}$ LS dan $106^{\circ} 49,50$ BT dengan ketinggian berkisar antara 550 - $570 \mathrm{~m}$ dpl. Dan lokasi keempat merupakan tataguna lahan dari tanaman semusim secara rotasi di dusun Cinagara dengan koordinat $06^{\circ} 44,58^{\prime}$ LS dan $106^{\circ}$ $50,49^{\prime}$ BT dengan ketinggian berkisar 560 $580 \mathrm{~m}$ dpl. Dalam lokasi tersebut, curah hujan rata-rata dalam kurun waktu 5 tahun terakhir berkisar $3500 \mathrm{~mm}$. Pengambilan sampel tanah dilakukan sekali pada tahun 2013.

Sedangkan, curah hujan rata-rata dari tahun 2008 s/d 2013 yang diperoleh dari stasiun Pasir Buncir yang terletak sekitar 3 $\mathrm{km}$ dari lokasi penelitian adalahsebesar 3256 $\mathrm{mm}$ dengan jumlah hari hujan rata-rata 134,4 hari.Cakupan lokasi daerah yang diteliti ditunjukkan pada Gambar 1.

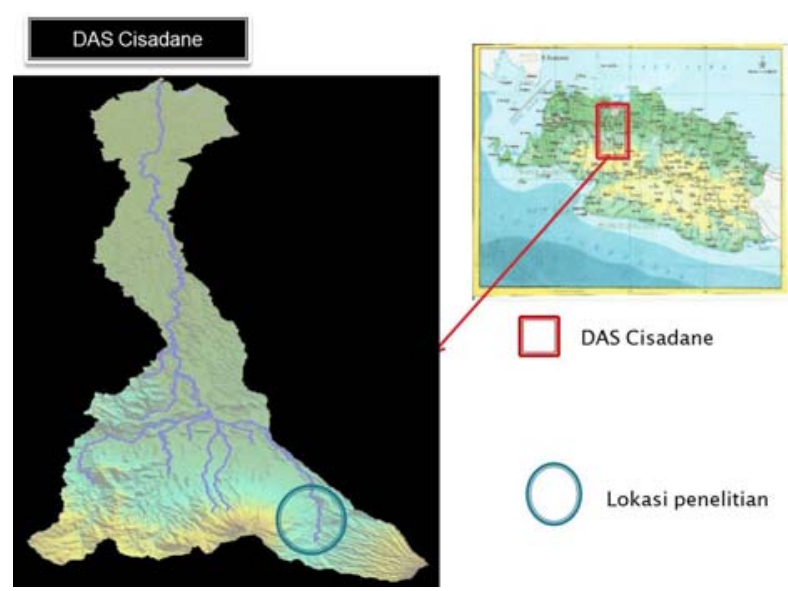

Gambar 1. Lokasi tataguna lahan yang diteliti 


\section{Pengambilan sampel untuk inventori pembanding}

Inventori pembanding merupakan hal yang sangat penting dalam penelitian menggunakan teknik radionuklida jatuhan karena akan diperlakukan sebagai nilai acuan baik untuk analisis kualitas maupun kuantitas. Untuk mengkaji redistribusi tanah, nilai inventori ini umumnya ditemukan pada lokasi-lokasi yang belum terganggu atau lokasi yang mengalami

\section{Pengambilan sampel tanah pada tataguna lahan}

Pengambilan sampel dilakukan secara transek yang mewakili kelerengan atas, tengah dan bawah dengan kedalaman core $20 \mathrm{~cm}$. Sampel yang diambil ini diperuntukkan untuk pengukuran inventori radionuklida jatuhan Cs-137 dan $\mathrm{Pb}-210$ excess. Sampel transek yang diambil dari masing-masing tataguna lahan beserta karakteristiknya dapat dilihat pada Tabel 1.

Tabel 1. Karakteristik fisik sampel yang diteliti

\begin{tabular}{|c|c|c|c|c|c|}
\hline $\begin{array}{l}\text { Kode } \\
\text { transek }\end{array}$ & $\begin{array}{l}\text { Jumlah } \\
\text { sampel }\end{array}$ & koordinat & $\begin{array}{l}\text { Ketinggian } \\
\text { (m.dpl) }\end{array}$ & Tataguna lahan dan dusun & $\begin{array}{c}\text { Kemiringan } \\
\text { lahan }(\%)\end{array}$ \\
\hline TKT & 3 & $\begin{array}{l}06^{\circ} 41,5^{\prime} \mathrm{LS} \\
106^{\circ} 46,9^{\prime} \mathrm{BT}\end{array}$ & 692 & $\begin{array}{l}\text { Kebun teh kurang terurus di } \\
\text { Cipelang }\end{array}$ & $20-30$ \\
\hline TRT & 3 & $\begin{array}{l}06^{\circ} 42,5^{\prime} \mathrm{LS} \\
106^{\circ} 46,0^{\prime} \mathrm{BT}\end{array}$ & 1110 & $\begin{array}{l}\text { Tanaman rumput ternak di } \\
\text { Cipelang }\end{array}$ & $20-30$ \\
\hline TKS & 3 & $\begin{array}{l}06^{\circ} 44,9^{\prime} \mathrm{LS} \\
106^{\circ} 49,5^{\prime} \mathrm{BT}\end{array}$ & 556 & $\begin{array}{l}\text { Tanaman Keras tumpangsari } \\
\text { dengan tanaman semusim di } \\
\text { Pasir Buncir }\end{array}$ & $10-20$ \\
\hline TTS & 3 & $\begin{array}{l}06^{\circ} 44,6^{\prime} \mathrm{LS} \\
106^{\circ} 50,5^{\prime} \mathrm{BT}\end{array}$ & 567 & $\begin{array}{l}\text { Rotasi tanaman semusim di } \\
\text { Cinagara }\end{array}$ & $10-20$ \\
\hline
\end{tabular}

gangguan sesedikit mungkin. Untuk itu, hutan pinus di kaki lerengan yang relatif datar dalam kawasan Taman Nasional Gunung Halimundi daerah Pasir Jaya dengan koordinat $06^{\circ} 43^{\prime} 06^{\prime \prime} \mathrm{S}$ dan $106^{\circ} 46^{\prime}$ $57^{\prime \prime} \mathrm{T}$ serta ketinggian berkisar $855 \mathrm{~m}$ dpl telah dipilih sebagai lokasi pembanding. Pada lokasi ini dilakukan pengambilan sampel tanah dengan interval kedalaman 2 $\mathrm{cm}$ sampai dengan $20 \mathrm{~cm}$. Disekitar titik pengambilan sampel profil kedalaman tersebut diambil sampel core dengan kedalaman $20 \mathrm{~cm}$ sebanyak 4 buah. Pengambilan sampel dengan cara ini bertujuan untuk mendapatkan nilai inventori pembanding yang diwakili oleh nilai rata-rata keempat cores.

\section{Analisis di Laboratorium}

Untuk mendapatkan nilai inventori masing-masing radionuklida $\mathrm{Pb}-210$ excess dan Cs-137, dilakukan pengukuran aktivitas dengan alat MCA (Multi Channel Analyzer) menggunakan low energy detector dengan efisiensi relatif $30 \%$ di dalam laboratorium PAIR, BATAN, khusus untuk cacahan latar rendah (low background counting). Sebelum pengukuran dilakukan dengan MCA, sampel dari lapangan harus dilakukan beberapa perlakuan. Sampel tanah dikeringkan, diagregasi, diayak dan ditimbang. Sebanyak 300-400 gr sampel kering dimasukkan dalam wadah khusus tabung merrinelli yang ditutup rapat dan dibiarkan selama kurang lebih 1 bulan. Dengan penutupan wadah sedemikian, diharapkan dalam waktu 1 bulan telah tercapai keseimbangan antara 
aktivitas Ra-226 dengan anak luruhnya. Aktivitas Cs-137 dalam sampel diukur berdasarkan cacahan pada energi $661 \mathrm{KeV}$. Aktivitas $\mathrm{Pb}-210$ excess dalam sampel diukur berdasarkan cacahan pada eneri $46,5 \mathrm{KeV}$ sebagai representasi dari aktivitas $\mathrm{Pb}-210$ total dan $\mathrm{Pb}-210$ supported melalui aktivitas $\mathrm{Pb}-214$ dengan energi $351 \mathrm{KeV}$ [13]. Aktivitas radionuklida $\mathrm{Pb}-210$ excess (Bq/kg) dan Cs-137 (Bq/kg) dalam sampel tanah ditentukan berdasarkan perbandingan secara langsung dengan material standar sekunder yang diukur di laboratorium Cina. Pengukuran dilakukan dengan geometri yang sama antara sampel tanah dengan material standar sekunder.

Selain pengukuran tersebut di atas, dari studi penelitian di tataguna lahan ini, pada lokasi yang hampir sama diambil juga sampel dengan kedalaman yang sama untuk tujuan pengukuran parameter kualitas tanah. Karena erosi dapat menyebabkan terjadinya penurunan kualitas tanah, maka diukur juga parameter kualitas tanah utama seperti kandungan total carbon, $\mathrm{N}, \mathrm{P}_{2} \mathrm{O}_{5}$, $\mathrm{K}_{2} \mathrm{O}$, dan tekstur tanah. Untuk pengukuran parameter kualitas tanah ini, sampel dikirim ke laboratorium tanah Institut Pertanian Bogor (IPB). Variabilitas kandungan parameter kualitas tanah, radionuklida $\mathrm{Pb}$ 210 excess, Cs-137 dan laju erosi berdasarkan konversi model dianalisis dengan model regresi linear untuk mencari korelasi diantaranya.

\section{HASIL DAN PEMBAHASAN}

\section{Profil Pb-210 excess dan Cs-137 pada lokasi pembanding}

Hasil pengukuran $\mathrm{Pb}-210$ excess dan Cs-137 pada lokasi pembanding disajikan pada Tabel 2, dan Gambar 2a-2b. Pada Tabel 2 dan Gambar 2a-2b dapat dilihat profil

Tabel 2. Aktivitas dan Inventori Pb-210 excess dan Cs-137

\begin{tabular}{clcccc}
\hline $\begin{array}{c}\text { Kode } \\
\text { sampel }\end{array}$ & $\begin{array}{c}\text { kedalaman } \\
(\mathrm{cm})\end{array}$ & $\begin{array}{c}\text { Aktivitas Pb-210 } \\
\text { excess }(\mathrm{Bq} / \mathrm{kg})\end{array}$ & $\begin{array}{c}\text { Aktivitas Cs-137 } \\
(\mathrm{Bq} / \mathrm{kg})\end{array}$ & $\begin{array}{c}\text { Inventori Pb-210 } \\
\text { excess }\left(\mathrm{Bq} / \mathrm{m}^{2}\right)\end{array}$ & $\begin{array}{c}\text { Inventori Cs-137 } \\
\left(\mathrm{Bq} / \mathrm{m}^{2}\right)\end{array}$ \\
\hline 1 & $(0-2)$ & 370,11 & 0,83 & 1326,48 & 2,97 \\
2 & $(2-4)$ & 165,08 & 1,28 & 1182,66 & 9,19 \\
3 & $(4-6)$ & 120,93 & 1,21 & 1003,73 & 10,05 \\
4 & $(6-8)$ & 102,20 & 1,28 & 886,09 & 11,08 \\
5 & $(8-10)$ & 58,12 & 1,40 & 657,49 & 15,84 \\
6 & $(10-12)$ & 53,63 & 1,38 & 703,47 & 18,15 \\
7 & $(12-14)$ & 42,45 & 1,58 & 445,72 & 16,55 \\
8 & $(14-16)$ & 27,66 & 1,41 & 321,56 & 16,42 \\
9 & $(16-18)$ & 18,87 & 1,15 & 267,69 & 16,31 \\
10 & $(18-20)$ & 13,02 & 0,92 & 140,46 & 9,96 \\
R1 & $(0-20)$ profil & - & - & 6935,34 & 126,53 \\
R2 & $(0-20)$ & 59,86 & 1,46 & 9527,78 & 233,07 \\
R3 & $(0-20)$ & 44,07 & 1,35 & 6879,36 & 210,62 \\
R4 & $(0-20)$ & 25,99 & 1,10 & 4316,56 & 182,11 \\
R5 & $(0-20)$ & 55,10 & 1,36 & 9439,82 & 233,19 \\
\hline & Rata-rata dari nilai R (R1, R2, R3, R4, R5) & 7420 & 197 \\
\hline
\end{tabular}

Catatan: Inventori R1 merupakan jumlah dari keseluruhan profil kedalaman dari 0-20 $\mathrm{cm}$ yang diperoleh dengan alat scrap, sedangkan R2...R 5 adalah inventori yang diperoleh dengan alat core. 
aktivitas $\mathrm{Pb}-210$ excess dan Cs-137 tiap interval kedalaman $2 \mathrm{~cm}$ dari sampel yang diambil dengan alat scrap dan hasil konversinya dalam inventori. Satu profil aktivitas dan 4 sampel bulk cores ini digunakan untuk menentukan nilai inventori pembanding. Profil dari aktivitas $\mathrm{Pb}-210$ excess memberikan gambaran yang ideal sebagai lokasi yang stabil yaitu adanya penurunan aktivitas secara eksponensial terhadap kedalaman serta aktivitas tertinggi ada di permukaan. Hal ini mengingat $\mathrm{Pb}-210$ excess merupakan radionuklida jatuhan yang diproduksi terus menerus karena adanya pelepasan gas Rn-222 dari tanah/batuan yang akan jatuh ke tanah dalam bentuk $\mathrm{Pb}$ 210 excess. Kurva dari profil aktivitas Cs- 137 idealnya mempunyai aktivitas tertinggi pada beberapa $\mathrm{cm}$ dari permukaan tanah dan setelah itu menurun secara eksponensial. Dari Gambar 2b terlihat jelas bahwa hal tersebut tidak terlihat, namun terlihat adanya kecenderungan relatif sama pada kedalaman antara 2 sampai $18 \mathrm{~cm}$. Adanya 2 fakta berbeda ini, memberikan informasi bahwa lokasi tersebut merupakan lokasi disturbed stabil atau lokasi yang telah mengalami perubahan profil tanah beberapa tahun sebelumnya, namun dapat diperkirakan sejak itu sampai kini lokasi ini tidak mengalami gangguan/erosi berarti.

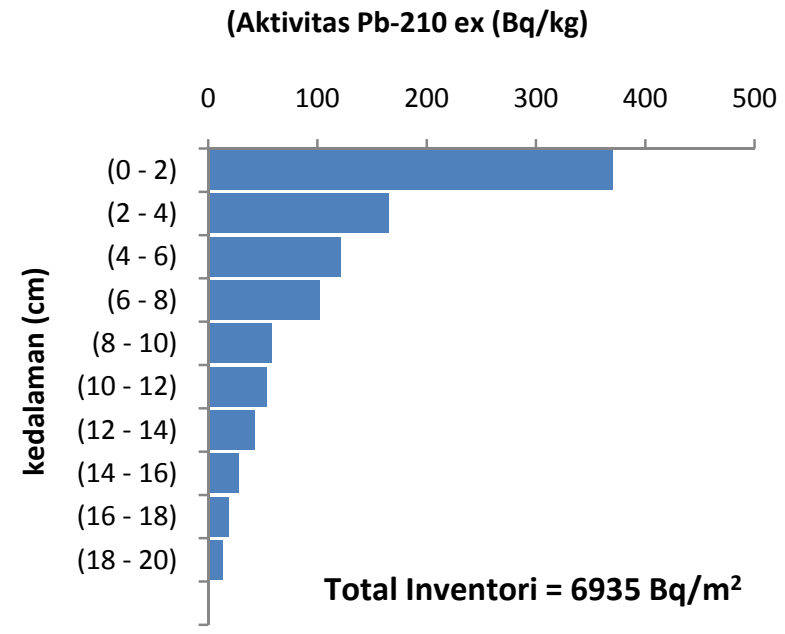

Gambar 2a. Profil aktivitas $\mathrm{Pb}-210$ excess dan total inventorinya di lokasi pembanding

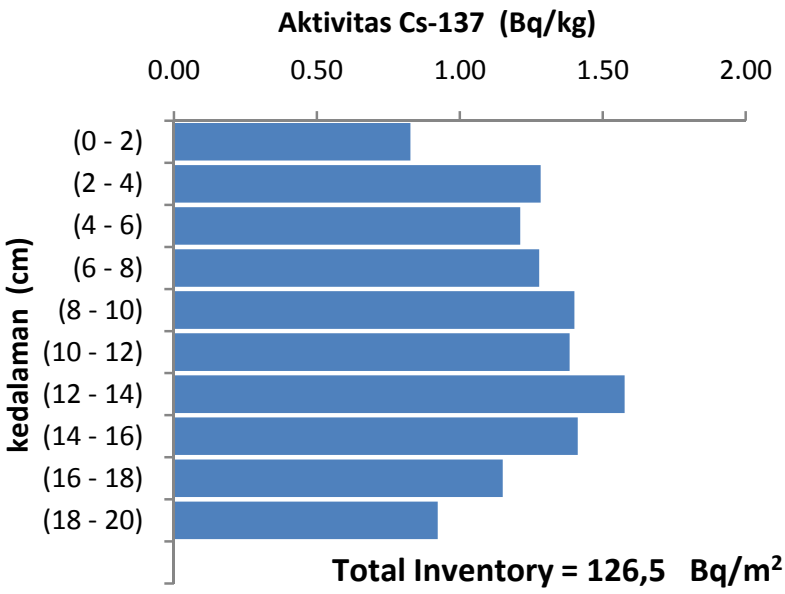

Gambar 2b. Profil aktivitas Cs-137 dan total inventorinya di lokasi pembanding

Dari Tabel 2 juga dapat dilihat bahwa inventori pada $\mathrm{R} 1$ yang merupakan inventori total dari profil kedalaman dari $0-20 \mathrm{~cm}$ berbeda dengan nilai inventori R2, R3, R4 dan R5 yang diambil dari lokasi sekitar, baik untuk Pb-210 excess maupun Cs-137. Dalam penelitian menggunakan radionuklida jatuhan, nilai inventori pembanding merupakan parameter yang sangat penting untuk penelitian terkait dengan estimasi erosi lahan. Satu sampel profil dan 4 sampel bulk cores digunakan untuk mendapatkan nilai inventori pembanding dalam model konversi yang digunakan. Standar error of the mean (SEM) digunakan untuk menyatakan variabilitas individu inventori terhadap nila rata-rata dengan tingkat kepercayaan $95 \%$ ditulis sebagai (mean $\pm 2 S E M)[14]$, dengan SEM adalah standard deviasi dibagi dengan akar jumlah sampel.

Nilai inventori $\mathrm{Pb}-210$ excess bervariasi dari $4316 \mathrm{~Bq} / \mathrm{m}^{2}$ sampai $9527 \mathrm{~Bq} / \mathrm{m}^{2}$. Dengan pendekatan tersebut nilai inventori pembanding $\mathrm{Pb}-210$ excess dinyatakan melalui rata-rata dengan $(7420 \pm 1728)$ $\mathrm{Bq} / \mathrm{m}^{2}$, dan koefisien variasi $29 \%$. Nilai inventori ini belum dapat dibandingkan dengan penelitian yang sama di sekitar lokasi, karena memang masih jarangnya penelitian terkait dengan pemanfaatan radionuklida ini untuk studi erosi. Nilai inventori ini lebih kecil dibanding dengan 
pembanding di Baiquan County, China yaitu (9550 \pm 2341$) \mathrm{Bq} / \mathrm{m}^{2}$ [4] dan lebih kecil juga dibanding inventori pembanding di Transylvanian Plain, Romania yaitu 9640 $\mathrm{Bq} / \mathrm{m}^{2}$ [13].

Nilai inventori Cs-137 di lokasi pembanding bervariasi dari $126 \mathrm{~Bq} / \mathrm{m}^{2}$ sampai $233 \mathrm{~Bq} / \mathrm{m}^{2}$. Dan dengan cara yang sama, nilai inventori pembanding Cs-137 dinyatakan melalui rata-rata dan dua standar error mean (SEM) dengan $(197 \pm 36) \mathrm{Bq} / \mathrm{m}^{2}$, dan koefisien variasi $23 \%$. Nilai inventori Cs-137 ini sangat mendekati dengan nilai inventori di daerah Ciawi yaitu $205 \mathrm{~Bq} / \mathrm{m}^{2}$ atau $268 \mathrm{~Bq} / \mathrm{m}^{2}$ pada tahun 2002 [11]. Nilai inventori ini mempunyai nilai yang lebih rendah dibandingkan dengan lokasi pembanding di Nganjuk-Jawa Timur yaitu $239 \mathrm{~Bq} / \mathrm{m}^{2}$ atau mempunyai nilai inventori $281 \mathrm{~Bq} / \mathrm{m}^{2}$ pada tahun 2006 [3].
Hasil pengukuran aktivitas $\mathrm{Pb}-210$ excess dan Cs-137, inventori dan konversi model

Hasil pengukuran inventori sampel tanah dari 4 jenis tataguna lahan disajikan pada Tabel 3 dan sifat fisika-kimia yang diukur di laboratorium IPB (Institut Pertanian Bogor) dapat dilihat pada Tabel 4. Dari Tabel 3 terlihat bahwa nilai aktivitas $\mathrm{Pb}-210$ excess dan Cs-137 keseluruhan terukur secara baik. Berbeda dengan hasil penelitian di Daerah Nganjuk pada tahun 2006 [3] yang mana banyak titik sampling dalam transek tidak dapat terukur karena erosi yang besar dan telah lama berlangsung. Hal ini menunjukkan bahwa di sekitar daerah penelitian ini masih cukup memberikan harapan untuk penelitian lebih lanjut pemanfaatan radionuklida jatuhan dalam 10-20 tahun ke depan, dan khususnya

Tabel 3. Aktivitas, Inventori dan redistribusi tanah di tataguna lahan

\begin{tabular}{|c|c|c|c|c|c|c|}
\hline \multirow{2}{*}{$\begin{array}{c}\text { Kode } \\
\text { sampel/nilai } \\
\text { rata-rata }\end{array}$} & \multicolumn{2}{|c|}{ Aktivitas (Bq/kg) } & \multicolumn{2}{|c|}{ Inventori (Bq/m2) } & \multicolumn{2}{|c|}{$\begin{array}{l}\text { Estimasi laju erosi } \\
\text { (ton/ha/th) }\end{array}$} \\
\hline & $\mathrm{Pb}-210$ ex & Cs-137 & $\mathrm{Pb}-210$ ex & Cs-137 & $\mathrm{Pb}-210$ ex & Cs-137 \\
\hline TKT atas & 16,80 & 0,31 & 3988,23 & 74,36 & $-20,7$ & $-29,16$ \\
\hline TKT tengah & 15,21 & 0,32 & 3212,57 & 66,95 & $-28,1$ & $-30,92$ \\
\hline TKT Bawah & 19,61 & 0,76 & 4868,33 & 193,14 & $-14,0$ & $-0,92$ \\
\hline Rata-rata. & 17,21 & 0,46 & 4023,04 & 111,49 & $-20,9$ & $-20,3$ \\
\hline TRT atas & 30,63 & 0,91 & 6285,36 & 187,75 & $-5,2$ & $-1,87$ \\
\hline TRT tengah & 20,07 & 0,61 & 4227,71 & 128,02 & $-17,6$ & $-13,96$ \\
\hline TRT Bawah & 20,17 & 0,33 & 3682,83 & 60,61 & $-22,0$ & $-27,61$ \\
\hline Rata-rata & 23,62 & 0,62 & 4731,96 & 125,46 & $-14,9$ & $-14,5$ \\
\hline TKS atas & 13,26 & 0,65 & 3145,03 & 153,96 & $-28,3$ & $-9,79$ \\
\hline TKS tengah & 12,28 & 0,43 & 2459,84 & 86,31 & $-36,6$ & $-25,17$ \\
\hline TKS Bawah & 13,06 & 0,84 & 3065,85 & 197,00 & $-29,2$ & 0,0 \\
\hline Rata-rata & 12,87 & 0,64 & 2890,24 & 145,76 & $-34,4$ & $-11,7$ \\
\hline TTS atas & 10,47 & 0,28 & 1625,73 & 42,89 & $-44,4$ & $-25,16$ \\
\hline TTS tengah & 7,36 & 0,41 & 1192,54 & 66,68 & $-53,8$ & $-21,27$ \\
\hline TTS Bawah & 9,05 & 0,86 & 1443,95 & 137,32 & $-47,9$ & $-9,74$ \\
\hline Rata-rata & 8,96 & 0,52 & 1318,25 & 102,00 & $-48,7$ & $-18,7$ \\
\hline
\end{tabular}


untuk Cs-137. Nilai inventori Pb-210 excess dan Cs-137 di setiap titik sampling bervariasi baik dalam satu transek maupun antar transek. Dibandingkan dengan nilai inventori pada lokasi pembanding mempunyai nilai lebih kecil, sehingga dapat diartikan bahwa pada titik sampling pada setiap tataguna lahan telah mengalami erosi. Nilai inventori untuk Pb-210 excess dan Cs137 bervariasi dari $1192 \mathrm{~s} / \mathrm{d} 6285 \mathrm{~Bq} / \mathrm{m}^{2}$ dan $42 \mathrm{~s} / \mathrm{d} 197 \mathrm{~Bq} / \mathrm{m}^{2}$.

Estimasi laju erosi yang ditunjukkan pada Tabel 3 merupakan hasil perhitungan dengan menggunakan konversi model yang dikembangkan oleh Walling D.E dalam software Cs-PB-Be model, dimana konversi model untuk $\mathrm{Pb}-210$ excess menggunakan model keseimbangan massa I dan untuk Cs137 menggunakan model proporsional [11]. Penggunaan model yang berbeda tersebut dengan pertimbangan bahwa fluks jatuhan $\mathrm{Pb}-210$ excess terjadi terus-menerus dari lingkungan sekitar, sementara Cs-137 tidak ada lagi jatuhan sejak tahun 1963. Sedangkan laju erosi yang diperoleh merupakan laju erosi rata-rata tahunan yang dihitung selama kurun waktu dari 19632013.

Dari Tabel 3 terlihat dua tataguna lahan pertama yaitu kebun teh yang tidak terawat (TKT) dan tanaman rumput gajah yang terawat (TRT) menghasilkan laju erosi dalam transek yang hampir sama. Kebun teh ini ditanam sejak jaman belanda dan telah mengalami beberapa peremajaan dan sejak tahun 1998-an mulai kurang terurus. Tataguna lahan tanaman rumput ternak dimullai sejak tahun 1993/1994 untuk mendukung kegiatan Balai Embrio Ternak, yang sebelumnya berupa belukar. Kedua tataguna lahan berlereng ini dapat dipertimbangkan telah mengalami olah tanah homogen dalam kedalaman olah $(20$ $\mathrm{cm})$ sebelum ditanami. Dua tataguna lahan yang lain yaitu lahan kebun dengan tanaman keras dan tumpangsari dengan tanaman semusim (TKS) bertopografi teras konvensional dan memberikan nilai estimasi laju erosi yang lebih besar berdasarkan $\mathrm{Pb}$ -
210 excess, begitu juga pada tataguna lahan dengan rotasi tanaman semusim (TTS).

Meskipun, secara umum dapat dikatakan bahwa estimasi laju erosi pada keempat transek tersebut didapatkan bahwa hasil estimasi dengan $\mathrm{Pb}-210$ excess berdasarkan keseimbangan massa diperoleh hasil relatif lebih besar dibandingkan dengan metode dari 12 sampai 20 ton/ha/th dan 15 sampai 49 ton /ha/th masing-masing berdasarkan Cs-137 dan $\mathrm{Pb}-210$ excess (Tabel 3 dalam rata-rata estimasi laju erosi).

Perubahan tataguna lahan pada TKS dan TTS berturut-turut, daritahun 1960 s/d 1987 merupakan kebun karet, tahun 1987 s/d 1998 adalah semak belukar dan sejak tahun 1998 diolah oleh masyarakat dengan tanaman semusim [16]. Dengan mempertimbangkan perubahan tataguna lahan dan profil ideal $\mathrm{Pb}-210$ excess dan Cs137 pada lokasi undisturbed [17], estimasi laju erosi berdasarkan $\mathrm{Pb}-210$ excess diperoleh jauh lebih besar dibanding berdasarkan Cs-137.

\section{Radionuklida Pb-210 excess, Cs-137 dan parameter kualitas tanah}

Untuk analisis lebih lanjut, perlu melihat parameter kualitas tanah yang dapat dilihat pada Tabel 4. Secara umum, parameter kualitas tanah utama yaitu persen $\mathrm{C}$ dan persen $\mathrm{N}$ pada lokasi pembanding lebih tinggi dari sampel transek. Hal ini memperkuat pertimbangan sebelumnya bahwa lokasi ini dapat dijadikan sebagai lokasi pembanding. Dengan data 4 transek pada Tabel 4 dan mengaplikasikan paket program statistik SPSS (Statistical Product and Service Solutions) 20 didapatkan bahwa ada korelasi positif antara parameter yang diukur tersebut. Aktivitas $\mathrm{Pb}-210$ excess dengan kandungan karbon $(\mathrm{r}=0,891)$, dengan kandungan $\mathrm{N}$ $(\mathrm{r}=0,747)$, dengan kapasitas tukar kation $\mathrm{Ca}++\quad(\mathrm{r}=0,708) . \quad$ Aktivitas Cs-137 berkoreasi positif dengan kandungan kapasitas tukar kation $\mathrm{Ca}++(\mathrm{r}=0,585)$ dan $\mathrm{Mg}++(\mathrm{r}=0,631)$. Persen kandungan karbon berkorelasi kuat dengan kandungan $\mathrm{N}$ $(\mathrm{r}=0,933)$ dan dengan kapasitas tukar kation 
$\mathrm{Ca}++(\mathrm{r}=0,864)$, serta adanya korelasi yang kuat antara $\mathrm{Ca}++$ dengan $\mathrm{Mg}++$ $(\mathrm{r}=0,710)$.

Dengan mempertimbangkan bahwa jatuhan radionuklida $\mathrm{Pb}-210$ excess dan Cs137 ke tanah permukaan akan diikat oleh partikel tanah, maka keduanya dikategorikan sebagai parameter tak bebas. Sedangkan parameter kualitas tanah seperti sifat kimia, sifat fisika dan kapasitas tukar kation dipertimbangkan sebagai parameter bebas. Analisis regresi linear dengan metode stepwise dengan memasukkan seluruh nilai parameter bebas ternyata hanya mendapatkan beberapa hubungan linearitas dengan kriteria kesalahan tidak lebih dari $5 \%$.
$50 \% \mathrm{Ca}++$ dalam tanah. Sebaliknya, kecenderungan tersebut lebih rendah terlihat dari Cs-137. Cs-137 berkorelasi positif masing-masing dengan $23 \%$ C, $33 \%$ $\mathrm{N}$ dan $34 \% \mathrm{Ca}++$ dalam tanah.

Analisis lebih lanjut menggunakan SPSS 20 dengan metode stepwise tidak didapatkan korelasi multiregresi dengan $\mathrm{C}$, $\mathrm{N}$ maupun $\mathrm{Ca}++$, sehingga $\mathrm{Pb}-210$ excessdan Cs-137 dalam tanah tidak dapat dinyatakan dengan ketiga parameter tanah tersebutsecara bersamaan. Ada korelasi kuat antara kandungan $\mathrm{C}$ dan kandungan $\mathrm{N}$, dan kedua parameter ini juga berkorelasi kuat dengan $\mathrm{Pb}-210$ excess yang mengindikasikan adanya kemungkinan besar $\mathrm{Pb}-210$ excess diikat juga pada organik karbon, disamping

Tabel 4. Inventori radionuklida dan sifat kimia-fisika sampel tanah

\begin{tabular}{lcccccccccc}
\hline \multirow{2}{*}{ Kode sampel } & \multicolumn{2}{c}{ Inventori $\left(\mathrm{Bq} / \mathrm{m}^{2}\right)$} & \multicolumn{3}{c}{ Sifat kimia } & \multicolumn{3}{c}{ Kapasitas tukar kation } & \multicolumn{3}{c}{ Sifat fisika } \\
\cline { 2 - 10 } & Pb-210 ex & $\mathrm{Cs}-137$ & $\% \mathrm{C}$ & $\% \mathrm{~N}$ & $\mathrm{Ca}++$ & $\mathrm{Mg}++$ & $\mathrm{K}+$ & pasir & debu & liat \\
\hline TKT atas & 3988,23 & 74,36 & 2,15 & 0,21 & 1,43 & 0,39 & 0,07 & 20 & 39 & 41 \\
TKT tengah & 3212,57 & 66,95 & 1,66 & 0,13 & 1,59 & 0,52 & 0,11 & 14 & 31 & 55 \\
TKT Bawah & 4868,33 & 193,14 & 2,08 & 0,15 & 0,79 & 0,31 & 0,24 & 19 & 35 & 46 \\
TRT atas & 6285,36 & 187,75 & 4,52 & 0,43 & 21,29 & 1,60 & 0,10 & 42 & 32 & 26 \\
TRT tengah & 4227,71 & 128,02 & 2,84 & 0,24 & 6,94 & 0,72 & 0,10 & 25 & 47 & 28 \\
TRT Bawah & 3682,83 & 60,61 & 1,89 & 0,17 & 2,48 & 0,38 & 0,07 & 37 & 43 & 20 \\
TKS atas & 3145,03 & 153,96 & 1,77 & 0,17 & 5,84 & 1,63 & 0,04 & 7 & 18 & 75 \\
TKS tengah & 2459,84 & 86,31 & 1,25 & 0,13 & 5,52 & 1,30 & 0,09 & 7 & 40 & 53 \\
TKS Bawah & 3065,85 & 197,00 & 1,62 & 0,19 & 3,18 & 0,83 & 0,06 & 4 & 33 & 63 \\
TTS atas & 1625,73 & 42,89 & 1,36 & 0,16 & 0,19 & 0,19 & 0,19 & 1 & 86 & 13 \\
TTS tengah & 1192,54 & 66,68 & 1,47 & 0,13 & 0,19 & 0,19 & 0,19 & 4 & 38 & 58 \\
TTS Bawah & 1443,95 & 137,32 & 1,65 & 0,22 & 5,32 & 1,51 & 0,11 & 14 & 17 & 49 \\
\hline Lokasi & \multirow{2}{*}{7420} & \multirow{2}{*}{197} & \multirow{2}{*}{4,25} & 0,45 & 1,53 & 0,3 & 0,24 & 56 & 31 & 13 \\
Pembanding & & & & & & & \multirow{2}{*}{0,19} \\
\hline
\end{tabular}

Hubungan linearitas tersebut dengan intersepnya dapat dilihat pada Gambar 3. Adanya korelasi positif dan hubungan yang kuat antara $\mathrm{Pb}-210$ excess dalam tanah dengan kandungan karbon (C), kandungan nitrogen $(\mathrm{N})$ dan kapasitas tukar ion $\mathrm{Ca}++$. Dengan kata lain, $\mathrm{Pb}-210$ excess berkorelasi masing-masing dengan $79 \% \mathrm{C}, 56 \% \mathrm{~N}$ dan partikel tanah [18]. Dengan tataguna lahan berbeda, hasil yang berbeda dilaporkan oleh Teramage et.al [19] bahwa ada korelasi positif yang kuat antara kandungan organik karbon tanah dengan aktivitas $\mathrm{Pb}-210$ excess dan Cs-137 dalam sedimen hasil erosi dari 3 jenis tanaman hutan. Hasil yang mirip didapatkan bahwa ada kecenderungan yang 


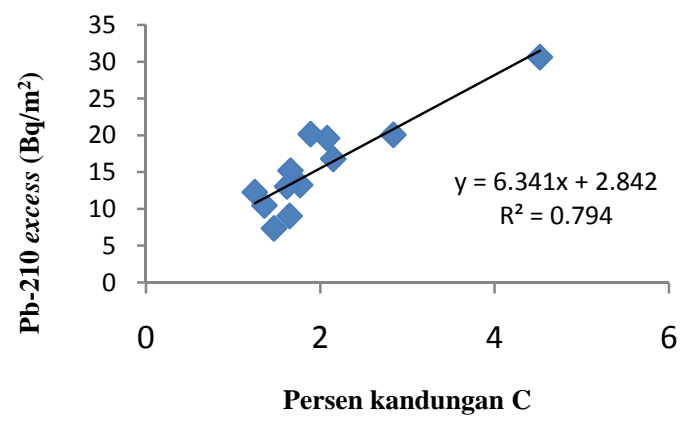

(a)



(b)

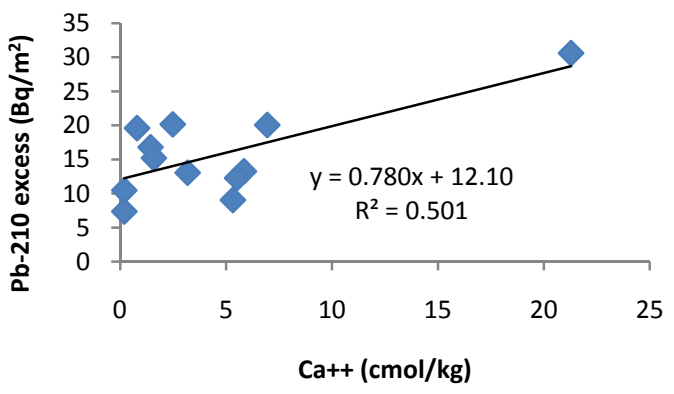

(c)

Gambar 3. Grafik kecenderungan hubungan radionuklida $\mathrm{Pb}-210$ excess dengan kandungan $\mathrm{C}$ (a) dan kandungan $\mathrm{N}(\mathrm{b})$; serta nilai tukar kation $\mathrm{Ca}++(\mathrm{c})$

lebih kuat korelasi linear antara organik karbon tanah terhadap $\mathrm{Pb}-210$ excess dibandingkan terhadap Cs-137.

Dalam kontek lingkungan secara global, tanah dikenal sebagai penyimpan karbon yang cukup tinggi sebagai hasil serapannya dari udara melalui jenis tanaman yang tumbuh dalam tanah. Begitu juga halnya proses serapan nitrogen dari udara ke dalam tanah. Oleh karena itu, kajian awal pada penelitian ini mengindikasikan adanya kemungkinan $\mathrm{Pb}-210$ excess sangat berpotensi digunakan dalam penelitian lebih lanjut terkait dengan dinamika transportasi tanah, akan tetapi sangat mungkin untuk mempelajari proses dan pengaruh serapan karbon dan nitrogen dari udara terhadap jenis tanaman atau tataguna lahan [19].

\section{KESIMPULAN}

Inventori $\mathrm{Pb}-210$ excess dan Cs-137 pada tiap tataguna lahan menunjukkan adanya variabilitas serta mempunyai karakteristik yang lebih dominan terhadap sifat kimia tanah dibandingkan dengan sifat fisika tanah, dan secara keseluruhan mempunyainilai yang lebih kecil dibanding lokasi pembanding.

Berdasarkan analisis parameter kualitas tanah pada lokasi transek dan lokasi pembanding serta model konversi radionuklida $\mathrm{Pb}-210$ excess dan Cs-137 pada masing-masing tataguna lahan, dapat diketahui bahwa pengelolaan dan pemanfaatan lahan dengan praktek pertanian yang ada dirasakan belum efektif untuk menekan laju erosi.

Kajian komparatif parameter kualitas tanah dengan aktivitas radionuklida jatuhan pada lahan dengan kelengkapan rekaman perubahan tataguna lahan, sangat membantu dalam melakukan analisis dan interpretasi perbedaan estimasi laju erosi yang diperoleh berdasarkan $\mathrm{Pb}-210$ excess dan Cs-137. 
Hasil uji statistik dengan metode
stepwise tidak didapatkan korelasi
multiregresi antara Pb-210 excess dan Cs-137 sebagai parameter terikat dengan kandungan $\mathrm{C}, \mathrm{N}$ maupun $\mathrm{Ca}++$ dalam tanah sebagai parameter bebas, sehingga $\mathrm{Pb}-210$ excess dan Cs-137 dalam tanah tidak dapat dinyatakan dengan ketiga parameter kimia tanah tersebut secara bersamaan. Namun demikian, ada hubungan linearitas/korelasi yang cukup kuat antara inventori $\mathrm{Pb}-210$ excess dengan kandungan organik karbon tanah $(79 \% \mathrm{C})$, dan dengan kandungan nitrogen $(56 \quad \% \quad \mathrm{~N})$ dalam tanah. Kecenderungan hubungan korelasi yang cukup kuat ini kurang terlihat untuk Cs-137. Hal ini menggambarkan bahwa Pb-210 excess dapat dijadikan sebagai tool lebih baik untuk mengetahui status kualitas tanah (sifat kimia) dari pada Cs-137. Begitu juga sebaliknya, Pb-210 excess juga dapat dijadikan sebagai perunut dari perpindahan organik karbon yang berasal dari tanah lebih baik dari Cs-137.

Analisis Pb-210 excess dalam tanah perlu dikembangkan lebih lanjut sebagai sarana untuk kuantifikasi kandungan karbon dalam tanah sebagai komponen dinamika karbon secara global.

\section{UCAPAN TERIMA KASIH}

Penulis mengucapkan banyak terima kasih kepada seluruh staf terkait dalam group sedimentologi-PAIR diantaranya Ibu Ir. Nita Suhartini yang membantu melakukan pengukuran dengan MCA, Bapak Darman dan Bapak Wagiyanto yang telah membantu dalam sampling dan preparasi serta penyiapan peralatan lapangan lain. Penulis juga mengucapkan banyak terima kasih kepada para reviewer dengan segala koreksi dan masukannya, sehingga karya tulis ini dapat dipublikasikan.

\section{DAFTAR PUSTAKA}

1. YANG, Y.H., YAN, B.X., and ZHU H; "Estimating Soil Erosion in
Northeast China Using ${ }^{137} \mathrm{Cs}$ and ${ }^{210} \mathrm{~Pb}_{\text {ex }}{ }^{\prime \prime}$, Pedosphere, 21-6, 706-711 (2011).

2. PORTO, P. ET, "Using Fallout Lead-210 Measurements to Estimate Soil Erosion in the Small Catchment in Southern Italy" $J$. Water Air and Soil Pollution, 6, 657-667 (2006).

3. BAROKAH, A., dan RAHMADI, S., Estimasi Laju erosi lahan berlereng di Kabupaten Nganjuk dengan Teknik Cs-137, J. Ilmiah Aplikasi Isotop dan Radiasi, 5 (2), 129-146 (2009).

4. LI YONG et.al., "Assessment of Effectiveness of Soil Conservation Measures in Reducing Soil Erosion and Improving Soil Quality in China Using Fallout Radionuclide Techniques", In: Impact of soil conservation measures on rosion control and soil quality, IAEATECDOC-1665, 207-224 (2011).

5. RITCHIE, J.C., NEARING, M.A., and RHOTON, F.E.,"Sediment budgets and source determinations jusing fallout Cesium-137 in a semiarid rangeland watershed, Arizona, USA., J. Environ. Radioavtiv, 100, 737-643 (2009).

6. BAROKAH, A., Model Estimasi aktivitas Cs-137 dalam contoh tanah melalui persentase organik karbon dan debu-liat, J. Ilmiah Aplikasi Isotop dan Radiasi, 3 (2), 11-24 (2007).

7. ALI, A.L, and BAROKAH, A., Preliminary study of sediment ages and accumulation rates in Jakarta bay derived from depth profile of unsupported $\mathrm{Pb}-210 .$, Indonesian J. Chemistry, 6 (3), 256-260 (2006).

8. BAROKAH, A., dan ALI, A. L., Fluks Deposisi $\mathrm{Zn}$ dan $\mathrm{Cr}$ di Muara 
Cisadane berdasarkan profil $\mathrm{Pb}-210$ unsupported dan siklus banjir 5 tahunan, J. Ilmiah Aplikasi Isotop dan Radiasi, 3 (1), 27-39 (2007).

9. WALLING, D.E., and He, Q., "Using Fallout Lead-210 Measurement to Estimate Soil Erosion on Cultivated Land", Soil Sci. Soc., Americal J., 63, 1404-1412 (1999).

10. MATISOFF GERALD, ${ }^{210} \mathrm{~Pb}$ as a tracer of soil erosion, sediment source area identification and particle transport in the terrestrial environment", $J$. Envi. Radioactivity, 138, 343-354 (2014).

11. WALLING, D.E., ZHANG, Y., and He, Q., "Model for deriving estimates of erosion and deposition rates from fallout radionuclide (Cs-137, $\mathrm{Pb}-210$ excess and Be-7) measurements and the development of user-friendly software for model implementation", In: Impact of soil conservation measures on rosion control and soil quality, IAEATECDOC-1665, 11-33 (2011).

12. IAEA Report, "IAEA/RCA Mid Term Project Review Meeting TCP on Restoration of Soil Fertility and Sustenance of Agricultural Productivity (RAS/5/039)", 13-23, limited Distribution, Vienna, Austria (2003).

13. BAROKAH, A., TOMMY, H., dan NITA, S., Laporan Teknis Pengembangan dan Aplikasi Teknik Isotop Alam untuk Penentuan Laju Erosi pada Skala Catchment, PATIR-BATAN (2010).
14. www.graphpad.com, "The SD and SEM are not the same", ${ }^{11995-2015}$ Graph Pad software, Inc. ALL Right Reserved.

15. IURIAN, A.R., et al., "Comparative assessment of erosion and deposition rates on cultivated land in the Transylvanian Plain of Romania using Cs-137 and $\mathrm{Pb}-210$ excess", J. Environ. Radioactivity, 125, 40-49 (2013).

16. Laporan Akhir Pengelolaan DAS Cisadane Terpadu tahun 2010, BP DAS Citarum Ciliwung (2010).

17. RAFIQ, M. et al, "Assessment of soil losses from managed and unmanaged sites in a subcatchment of Rawal Dam, Pakistan using fallout radionuclides", In: Impact of soil conservation measures on rosion control and soil quality, IAEA-TECDOC-1665, 73-85 (2011).

18. HANCOCK, R., MURPHY, D., and EVANS, K., "Hillslope and catchment scale soil organic carbon concentration : An Assessment of the role geomorphology and soil erosion in undisturbed environment, Geoderma, 155, 36-45 (2010).

19. TERAMAGE, M.T., et. al, "The relationship of soil organic carbon to $\mathrm{Pb}-210$ excess and Cs-137 during surface soil erosion in a hillslope forested environment", Geoderma 192, 59-67 (2013). 